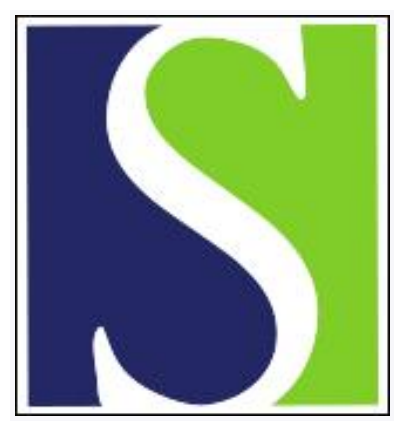

Scand J Work Environ Health 1991;17(2):81-90

https://doi.org/10.5271/sjweh.1728

Issue date: Apr 1991

\title{
Low-back pain, its origin and risk indicators.
}

by Riihimaki $\mathrm{H}$

Affiliation: Department of Epidemiology and Biostatistics, Institute of Occupational Health, Helsinki, Finland.

The following article refers to this text: 2016;42(2):125-134

This article in PubMed: www.ncbi.nlm.nih.gov/pubmed/1828614

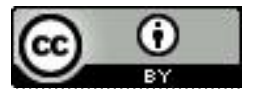




\title{
Low-back pain, its origin and risk indicators
}

\author{
by Hilkka Riihimäki, MD, MSc ${ }^{1}$
}

\begin{abstract}
RIIHIMÄKI H. Low-back pain, its origin and risk indicators. Scand J Work Environ Health 1991: 17:81-90. Low-back pain is a common ailment. Much is known of the pain-sensitive structures of the low back, but for a patient with acute low-back pain the cause can rarely be defined. Although the biochemical properties of the intervertebral discs and their degenerative changes have been unraveled, it is difficult to distinguish between pathological degeneration and normal changes due to aging. As a consequence of the problems in diagnosing back diseases, the most common measure of low-back morbidity in epidemiologic studies has been the occurrence of symptoms. A wide spectrum of work- and individualrelated factors have been found to be associated with low-back pain, but little is known about the extent to which these factors are etiologic and the extent to which they are symptom-precipitating or symptomaggravating.
\end{abstract}

Key terms: degeneration, lumbar spine, psychosocial factors, review, work load.

Low-back pain has been called the nemesis of medicine and the albatross of industry (1). This saying reflects the prevailing lack of understanding of the nature and etiology, and, consequently, the treatment of back diseases, as well as the great impact this group of diseases has in the industrial setting.

Epidemiologic investigations have shown that 60$80 \%$ of the population experiences back pain at some time during life (2-4)). Low-back pain can develop suddenly or gradually, with or without connection to an initiating event. In a Swedish study (5), two-thirds of the acute low-back patients reported that their back pain developed during recreational activities, often when the person bent forwards, and the onset of symptoms was usually sudden. For two-thirds of the patients with subacute symptoms, the initiation of pain had been gradual, and it usually started during the workday, but without connection to any special event. The back pain of patients with chronic symptoms had developed insidiously in more than half of the cases.

The exact cause of acute low-back pain cannot usually be defined. In patients who recover within two to three weeks, it seems likely that either a muscle sprain, a minor ligamentous injury, or synovitis of a facet joint could have given the nociceptive impulses, whereas, in patients exhibiting pain for four to eight weeks, a greater ligament or tendon injury is likely to have occurred. The healing time for a disc injury is considerably longer (6).

\footnotetext{
1 Department of Epidemiology and Biostatistics, Institute of Occupational Health, Helsinki, Finland.
}

Reprint requests to: Dr H Riihimäki, Department of Epidemiology and Biostatistics, Institute of Occupational Health, Topeliuksenkatu 41 a A, SF-00250 Helsinki, Finland.

\section{Origin of low-back pain}

All structures sensitive to pain are provided with particular nerve endings, nociceptors. Nociceptors can be activated by mechanical stress or exposure to irritating chemical substances in the surrounding tissue, such as lactic acid, potassium ions, bradykinins, prostaglandins, and histamine, that are released from traumatized, inflamed, or metabolically abnormal, especially ischemic, tissues (7).

In the lumbosacral region nociceptive nerve endings occur throughout the skin and subcutaneous and adipose tissue; the fasciae, aponeuroses, and ligaments; the vertebral periosteum and marrow; the adventitial sheaths of blood vessels; and the fibrous capsules of the lumbar facet and sacroiliac joints (7). In a normal adult intervertebral disc there are no nerve endings in the nucleus pulposus, and nociceptive endings have been detected only in the fibroelastic tissue that binds the posterior surface of the annulus fibrosus to the posterior ligament (7-9). Vernon-Roberts \& Pirie (10) detected vascular in-growth, with accompanying nerve endings, into the discs through breaches in the cartilage end plates (Schmorl's nodes) or clefts in the annulus fibrosus. Thus low-back pain can originate from nearly all tissues in the lumbosacral area.

The exact location of the origin of pain in the back is difficult to establish owing to, among other things, complex, anastomotic innervation of the spinal tissues (7). Vernon-Roberts (11) proposed the following sites from which low-back pain could arise: (i) the interior of a disc following in-growth of nerves accompanying vascularization of clefts and prolapses, (ii) pain-sensitive structures (ligaments, dura matter, nerve roots), on which pressure is applied by spondylophytes, (iii) posterolateral disc prolapses or stabilizing osteophytes impinging on nerve roots in intervertebral foramina, (iv) apophyseal joints with osteoarthrosis, (v) pseu- 
doarthroses (osteophytes impinging upon the dorsal surfaces of the laminae of the neural arches) formed on the vertebrae following disc degeneration, (vi) fractures of facets or facetal end plates of the apophyseal joints, (vii) an area of the spinal canal that has been narrowed by posterior disc prolapses and apophyseal osteophytes, particularly when there is already a narrow spinal canal, and (viii) trabecular microfractures in vertebral bodies in association with osteoporosis and Schmorl's nodes. He pointed out that it is possible that there is some pain-inducing pathology in clinically and radiologically "normal" spines.

Many studies have shown that degenerative changes detected in the lumbar spine in plain radiographs are associated with an increased risk for low-back pain (12- 19), but there are also several studies in which such an association has not been detected (20-22). My co-workers and I (23) found that degeneration of the lumbar spine is associated with sciatic pain but not with lumbago or nonspecific back pain. Comparison of these studies is difficult because the classification of radiographic findings varies from one study to another.

Low-back pain may be associated with symptoms in a leg. A common cause for back pain radiating to a leg (ie, sciatic pain) is a herniated lumbar intervertebral disc. However, there is experimental evidence that referred leg pain may also arise from irritation of other deep tissues. Mechanical irritation of the posterior annulus fibrosus, the dorsal longitudinal ligament, and the nerve root have been shown to elicit sciatic pain (24), and chemical (hypertonic saline) irritation of the facet joint has caused similar pain (25).

The herniated lumbar intervertebral disc was first discovered by Mixter \& Barr in 1934 (26). After this discovery it was hoped that back problems could be solved surgically, but today it is known that this is not the case. With modern imaging techniques, such as computerized tomography (CT), magnetic resonance imaging (MRI), and CT discography, the status of the intervertebral discs can be determined better than before. In clinical practice, when the patients' symptoms and clinical signs concur with the finding of a herniated disc, there are good grounds to presume that the disc disease causes the pain.

However, there is accumulating evidence that disc herniations are common in people with no back pain $(27-28)$ and that in discography positive findings are frequent in symptomless people (29-31). Using MRI, Boden and his co-workers (28) found at least one herniated intervertebral disc in $24 \%$ and spinal canal stenosis in $4 \%$ of symptomless volunteers aged 20 to 80 years. In 20 - to 59-year-olds the prevalence of herniated disc was $22 \%$, and in 60 - to 80 -year-olds it was $36 \%$. Spinal stenosis was detected only in the older age group, for which the prevalence was $21 \%$. At least one level of disc degeneration was noted in $36 \%$ of the younger and in $98 \%$ of the older group of asymptomatic volunteers.
MRI has made it possible, for the first time, to examine the disc status of symptomless people without any known adverse health effects; all other radiologic techniques expose subjects to radiation. However, before MRI is applied in larger population studies, the correspondence between MRI findings and the pathoanatomic status of the disc must be evaluated. MRI offers the possibility to determine why some people with disc herniations have symptoms and others do not. One possible predisposing factor seems to be the relative narrowness of the spinal canal (32-33). Changes in the chemical environment of the nerve and ischemia due to diminished blood supply have been suggested as intermediary steps beyond simple compression of the nerve root and the dorsal sensory ganglion in cases of a symptomatic herniated disc (34).

Difficulties in determining where the low-back pain originates, even with the most sophisticated clinical methods, means difficulties in defining the underlying disease. Thus it is not surprising that in epidemiologic studies the outcome has been measured by symptoms and signs (most frequently radiologic findings). In etiologic research, low-back pain may not be a good indicator of back disease. In addition to low-back pain being nonspecific, it is also possible that the occurrence and/or perception of symptoms is different between the "exposed" and "unexposed" (eg, heavy versus light physical work) subjects with the same underlying disease.

Only a few epidemiologic studies have been done in which the outcome has been more specific, namely, herniated disc (35-39). In these studies also the index series has consisted of people with symptomatic herniated discs, and thus the detected associations between herniated disc and the determinants may be biased. The generalization of the results to disc herniations per se should be done with caution.

\section{Degeneration of the intervertebral disc}

The intervertebral disc forms the articulation between the vertebral bodies. The disc is composed of two morphologically different parts, the annulus fibrosus and the semigelatinous nucleus pulposus. In children the discs are vascularized, but an adult's discs are avascular (40). Nutrition of a disc takes place by diffusion through cartilaginous end plates opposing the vertebral bodies and the annulus $(41-42)$.

The nucleus pulposus contains $80-90 \%$ water in early life. The water content decreases with increasing age and is $70 \%$ in the sixth decade. The water content of the annulus is lower, 60 to $70 \%$, and it does not change markedly with age.

The major components of t:? disc matrix are collagen and proteoglycans. The nucleus pulposus contains $10-20 \%$ and the annulus 50 to $60 \%$ collagen per dry weight. This pattern changes little with aging, but the proteoglycan content per dry weight decreases 
with increasing age. The proteoglycan content of the annulus is $20 \%$ and that of the nucleus $65 \%$ in early life, whereas in the sixth decade the figures are 10 and $30 \%$, respectively (43). Collagen is responsible for the tensile strength of the annulus, and proteoglycans for the hydrodynamic properties of the nucleus. There is progressive loss of resilience and turgescence of the disc as age advances.

The term disc degeneration is an arbitrary one. It does not denote any specific pathological change. An intervertebral disc presenting features commonly found in the sixth decade could be described as a "degenerated disc" when found in a man 30 years of age (44). One important goal for future research is to differentiate between pathological degeneration and normal age changes in the disc (45).

According to Macnab (44) the three main histological changes in aging discs are the destruction of the hyaline cartilage end plate, the increasing conversion of the gelatinous ground substance of the nucleus into formed elements, and the metaplasia of the annulus into fibrocartilage. Defects in the end plates interfere with the nutrition of the disc. Such defects are frequently followed by the growth of vessels in the disc derived from the vertebral spongiosa, and occasionally granulation tissue can be seen.

In premature degeneration the annulus may show radial tears which are the most common posterolaterally where the annulus is thinner than elsewhere. Sometimes these tears are associated with an extrusion of nuclear material. In addition there may be circumferential tears between the layers of the fibrous annulus. The fact that these clefts may contain fibrin and sometimes exhibit vascular ingrowth suggests that they are formed as the result of traumatic tearing rather than purely the result of a degenerative process (11).

End-plate fractures are compression failures which promote disc degeneration (46-48). Laboratory experiments have shown that in vitro torsional loading of spinal segments produces fissures in the annulus posterolaterally. Acute ruptures of the annulus can only be produced by combined flexion and lateral bending motions, but not by torsion (49). A previously damaged disc is more vulnerable than a healthy one.

Disc degeneration is associated with undue mobility in the motion segment, and this mobility promotes the growth of spondylophytes, especially of the traction spur type (44). However, spondylophytes are not always associated with disc degeneration (50). When the disc degenerates, its height is reduced. This phenomenon leads to a change in stress distribution in the motion segment and to secondary degeneration in the facet joints (51).

Disc degeneration is fairly advanced before it can be visualized in a radiograph as narrowing of the intervertebral space. Though plain radiographs have been in extensive use for decades, data on the correspondence between the pathoanatomic status of the disc and radiographic signs of disc degeneration are scant (52).

\section{Classification and natural course of back diseases}

The difficulty of making precise diagnoses is the single greatest problem of clinical work with patients with back symptoms, and in the research on back diseases as well.

Grabias \& Mankin (53) presented a classification of low-back pain which was based on etiologic factors (ie, mechanical, infectious, inflammatory, metabolic neoplastic, and visceral). According to this classification, the majority of people with low-back pain have mechanical causes, which include lumbosacral sprain/ strain, degenerative disc disease, spondylolisthesis, spinal stenosis, and fracture. This class is nonspecific, whereas the other five classes consist of specific diseases with exact diagnoses.

Nachemson \& Andersson (54) proposed a classification based on symptoms and clinical findings. They defined insufficientia dorsi, lumbago, sciatica, rhizopathy as a special form of sciatica, and lumbagosciatica. The following prefixes were also defined according to the onset and duration of symptoms: acute $(0-3$ months in duration, immediate onset), subacute ( $0-3$ months in duration, slow onset), chronic ( $>3$ months in duration), and recurring (symptoms recurred after an interval of no symptoms). A review of the literature indicated that this classification has not attained acceptance outside of Scandinavia.

In cases where the exact cause of low-back pain cannot be determined, it has been recommended to use such terms as "nonspecific" (55) or "idiopathic" back pain (45). Estimates of the proportion of all low-back pain for which no particular etiology can be specified range from $20 \%$ (56) to $85 \%$ (57). In part the variation depends on whether cases in which degenerative changes are seen radiographically in the intervertebral spaces are included in the category of idiopathic lowback pain or not. Back pain initially classified as idiopathic may be shown subsequently to have a definite pathologic etiology in patients followed for sufficiently long periods of time (45).

In a Swedish study (5), careful clinical examination did not reveal objective signs for about one-third of the back patients with acute or subacute symptoms (sick leave for one month) and two-thirds of those with chronic symptoms (sick leave for three months). In the groups without objective findings among the patients with acute or subacute symptoms, the rate of recovery was faster than in the groups with objective clinical signs.

According to a review by Nachemson (6), attacks of acute low-back pain tend to start at the age of 25 years. Symptoms subside in half of the patients within four weeks and in $90 \%$ within two months, 
and little can be done in the way of treatment to alter this course. The risk of recurrence over the following couple of years is about $60 \%$, but decreases during the third year. After six months 2-3 \% and after 12 months $1 \%$ of the low-back patients with acute symptoms are continually symptomatic. The mean age of the patients with chronic symptoms is about 50 years. In a recent Swedish study of people who were on sick leave due to back disease, $57 \%$ returned to work within a week, almost $90 \%$ within six weeks, and $95 \%$ within 12 weeks (58).

\section{Risk indicators of low-back disorders}

Hildebrandt (59) made a review of epidemiologic studies on risk factors of low-back pain using five comprehensive publications on low-back pain from the 1980 s, three books $(60-62)$, and two review articles $(63,64)$. He found 24 work-related factors which were regarded as risk indicators of low-back pain by at least one of the following sources: general: heavy physical work, work postures in general; static work load: static work postures in general, prolonged sitting, standing or stooping, reaching, no variation in work posture; dynamic work load: heavy manual handling, lifting (heavy or frequent, unexpected heavy, infrequent, torque), carrying, forward flexion of trunk, rotation of trunk, pushing/pulling; work environment: vibration, jolt, slipping/falling; and work content: monotony, repetitive work, work dissatisfaction. The list of "generally accepted" risk factors (ie, factors mentioned by at least three sources) was reduced to the following eight: general: heavy physical work; static work load: prolonged sitting; dynamic work load: heavy manual handling, heavy or frequent lifting, trunk rotating, pushing/pulling; work environment: vibration.

There were 55 individual factors mentioned by at least one of the sources as a risk indicator of low-back pain. They were as follows: constitutional: age, gender, weight, back muscle strength (absolute and relative), fitness, back mobility, genetic factors; postural-structural: severe scoliosis, difference in leg length; radiographic: severe multilevel degeneration, disc resorption, disc herniation, severe arthrosis of facet joints, spondylarthropathies, spondylolysis, spondylolisthesis, sacralization/transitional vertebra, skeletal defects, fractures, neoplasmata, severe kyphosis, lumbar kyphosis; medical: back complaints in the past, infectious diseases, pregnancies, number of pregnancies and childbirths; psychosocial: depression, anxiety, "life events," family problems, divorce, personality, hypochondriasis, somatization, dissatisfaction with work or social status of work, tense and fatigued after work, high degree of responsibility and mental concentration, poor intellectual capacity, poor ability to establish emotional contacts, less "philosophic" attitude; demographic: socioeconomic situation, edu- cational level, location of home; other: sports, degree of physical activity, gardening, caring of grandchildren, smoking, alcohol, coughing, work experience. Only the following six risk factors were "generally accepted': constitutional: age, relative muscle strength, physical fitness; medical: back complaints in the past; psychosocial factors (not specified); other: work experience.

The following 18 factors were mentioned as nonrisk factors: constitutional: body build, height/weight indices; postural-structural: kyphosis, lordosis; radiographic: nonspecific radiographic abnormalities, Schmorl's nodes, osteophytes, disc narrowing, facet asymmetry, spina bifida occulta, osteoporosis, lordosis, scoliosis and increased lumbosacral angle; medical: severe mental problems like psychosis and neurosis; demographic: ethnic factors, marital status. Of the nonrisk factors, nonspecific radiographic abnormalities were considered of no importance by almost all the sources.

Most $(74 \%)$ of the risk and nonrisk factors were only mentioned in one or two sources, and for $22 \%$ no reference and for $48 \%$ only one reference was given. Hildebrandt concluded that the interpretation of the vast amount of epidemiologic data on the correlates of low-back pain is difficult.

The review depicts clearly the confusion that prevails today in the field of epidemiology of low-back pain. Most epidemiologic studies have been made on population cross-sections with retrospective experience of exposure and outcome. The most commonly used measure of outcome has been the occurrence of lowback pain based on questionnaire or interview data.

It is not surprising that low-back pain has been found to be related to such a variety of factors. The prevalence of nonspecific low-back pain is high in all populations, and thus there is a good chance of obtaining a relationship between any infrequent healthrelated characteristic of a population and the prevalence of low-back pain, especially since health problems tend to cluster in populations (65).

Problems may arise in etiologic considerations when symptoms are used as the indicator of a disease. Some factors which aggravate symptoms or modify the perception of symptoms may appear as risk indicators of symptoms even though they are not risk indicators of the underlying disease.

\section{Work-related factors}

Heavy physical work. Many cross-sectional studies have indicated that low-back pain is related to heavy physical work $(4,13,14,66-73)$, but there are also studies in which such a relationship has not been detected $(74,75)$. In most of these studies work was classified as heavy on the basis of general impression without any attempt to analyze the back-loading factors in more detail. In some studies (4) the data on the heaviness of work was also based on subjective per- 
ception, which may be influenced by the occurrence of back trouble.

An 11-year follow-up of a Finnish population sample revealed that blue-collar workers had a higher incidence of hospitalization due to herniated lumbar disc or sciatica than white-collar workers (77). A sample of Finnish employees in the metal industry has been followed for 10 years. Both in the cross-section and follow-up, low-back pain was more common among the blue-collar workers than among the white-collar workers. For the blue-collar workers, however, the associations between the indices of physical work load and musculoskeletal morbidity were weak or nonexistent (78), possibly because of small variation within the sample. In a one-year follow-up of a Danish sample of the general population, occupational factors did not predict the occurrence of low-back pain (79).

The results of many studies indicate that radiographically detectable degenerative changes of the lumbar spine are related to heavy work $(12-14,19$, $66,75,80,81)$.

Lifting, carrying, pulling and pushing. Loading of the spinal tissues is not harmful unless the endurance of the tissues is exceeded. This excess may be caused by sudden overload or fatigue in repeated loading (82). Gradual increase in loading has a training effect, and muscles, tendons, and also vertebrae adapt to endure heavier loads. As an example, weight lifters have been shown to have less degenerative changes in the lumbar spine than men in heavy physical work (13). A high level of physical activity strengthens both the vertebrae and the discs (83).

Lifting and other sudden motions are often claimed to be the immediate precipitating event in low-back pain. At the Boeing company, improper lifting was the most common self-reported cause of back injury (84), and also among Scottish miners and office workers recent low-back pain was most commonly attributed to lifting (73).

With regard to the long-term effects, several studies indicate that the occurrence of low-back pain is related to lifting, carrying, pulling, pushing, or other sudden maximal efforts $(4,66,85-91)$. Chaffin \& Park (87) reported that a mismatch between the lifting strength requirements of a job and workers' lifting capacity increase the risk for low-back injuries. They also found that the risk is greater when the frequency of lifts is high or low in comparison with the intermediary frequency.

In a case-referent study (36) herniated lumbar intervertebral disc was not related to lifting. However, in a later similar study an increased risk of herniated disc was found in jobs involving heavy lifting combined with twisting and bending (37).

Twisting, bending and other nonneutral trunk postures. Often nonneutral trunk postures are associated with lifting, and thus it may be difficult to evalu- ate the isolated effect of such postural load on the back. A relationship has been shown between nonneutral postures and back pain in several studies (66, $73,88,92$ ). Keyserling and his co-workers (93) observed the occurrence of nonneutral trunk postures for each of the study subjects in a case-referent study in an automobile assembly plant and found low-back pain to be related to nonneutral trunk postures. My co-workers and I (94) found a relationship between sciatic pain and working in twisted or bent postures (self-report) also among office workers whose work rarely involved the lifting of heavy loads.

Motor vehicle driving. There is mounting evidence that motor vehicle driving is positively associated with risk for low-back pain $(68,88-90,95,96)$, for sciatic pain $(91,94)$, and for herniated intervertebral disc $(38,77$, 97-99). An increase in the prevalence of radiographically detectable degenerative changes of the lumbar spine has also been found among motor vehicle drivers $(100,101)$.

It is suggested that whole-body vibration combined with prolonged sitting has a deleterious effect on the back. Occupational exposure to whole-body vibration is frequently associated with other back loading factors at work, such as manual materials handling, and therefore the interpretation of the results from epidemiologic studies is ambiguous (102). In addition usually no differentiation between shocks and vibration exposure in terms of frequency, or a distinction between the directional components of vibration, has been made (103). However, there is accumulating experimental evidence supporting the view that wholebody vibration in a seated posture is harmful to the back (82).

Sitting. Some studies have indicated that low-back disorders are related to prolonged sitting or sedentary work $(36,66,85)$, but there are also several studies in which no such relationship has been detected $(4,37$, $77,94,104-106)$. Thus, evidence for a relationship is scarce, even though it can be considered biologically plausible. It has been shown that the intradiscal pressure is increased in the sitting posture, especially when one sits erect without support $(107,108)$. It is also possible that prolonged static sitting postures may have a deleterious effect on the nutrition of the intervertebral disc (109).

Other work-related factors. Various psychological and psychosocial factors related to work, such as monotonous work and job dissatisfaction $(4,90,105,110)$ have been reported to be associated with the occurrence of low-back pain. Most of the studies have been retrospective, and it is thus difficult to determine whether psychological features are antecedents or consequences of back pain (111). It is also difficult to de- 
termine whether these factors play a role in the etiology of low-back diseases or only affect the perception of symptoms and sickness behavior. In a prospective study among about 3000 aircraft employees psychosocial factors at the workplace were better predictors of future back injuries than physical findings (112).

\section{Trauma}

It is plausible that trauma is of importance in the development of back disorders. In true accidental injuries this connection is more obvious than in nonaccidental injuries in which there is no disruption of the normal pattern of work and the first unexpected event is pain in the back (63). In a prospective study by Lloyd \& Troup (113), in about one-third of the attacks of low-back pain there was a truly accidental event, in one-fifth a nonaccidental injury, and for the rest there was no indication of any kind of injury. Truly accidental injuries, especially falls, had a worse prognosis than the others. In an analysis of back injuries Manning et al (114) found that two-thirds of true accidental injuries were "underfoot accidents" (slipping of foot, etc), and "handling" was the cause in nearly one-third. In nonaccidental injuries handling was recorded for $63 \%$ of the cases.

The risk of sciatic symptoms has been reported to be increased among workers who have earlier had back accidents $(76,115)$. Repeated compressive stress can cause microfractures in the end plates and subchondral bone of the vertebrae $(10,47,116)$, but it has been suggested that torsional load contributes more to the development of disc degeneration than compressive loads (117).

Repeated minor injuries are presumed to cause irreversible damage and hasten the degenerative process in the spine (118). Degenerated vertebral units are more liable to fail under mechanical stress than healthy ones (119).

\section{Individual characteristics}

According to earlier retrospective or cross-sectional studies, the occurrence of low-back pain increases with increasing age up to about 50-60 years of age, after which there is a decline $(13,14,71,120,121)$. Some prospective studies have, however, revealed that there is no distinct age dependency $(3,122)$. Men and women tend to be affected with equal frequency $(71,120,123)$.

The results from studies on the relationship between anthropometric measures and back disorders are conflicting. In some studies $(69,97,115,124)$ taller people have been found to be at greater risk for low-back pain, but not in others $(38,73,84,125)$. Likewise, a positive relation between excess body weight and risk for low-back disorders was shown in some studies (97, $122,124,126)$ but not in others $(38,69,125,127)$.

General physical fitness, measured as aerobic capacity, has not been shown to predict low-back pain (69, 122). Cady and his co-workers (128) found that fire- fighters who were unfit had the most injuries, but that the fittest of the firefighters suffered the most severe injuries.

Many cross-sectional studies have shown that people with a history of low-back disorders have weaker trunk muscles than those without such a history (129131). Imbalance between trunk flexor and extensor muscle strength has been detected in individuals with low-back disorders (132-134). In two prospective studies, the weakness of trunk muscles was not associated with the incidence of low-back pain among previously healthy people $(132,135)$. In the prospective Boeing study a positive relationship was detected between isometric strength and the occurrence of back injuries (136). This relationship did not however, remain after adjustment for age and gender.

Smoking has been found in many studies to be related to the occurrence of back disorders $(38,69,79$, $89,91,122,126,137,138)$, but there are also studies which have failed to show such a relationship (115). There is experimental evidence that smoking impairs the nutrition of the intervertebral discs however (139).

Individuals with low-back disorders have been shown to have a higher frequency of psychological symptoms than those without disorders $(88,140-143)$. Most of the reports on the relationship between lowback disorders and psychological factors are from cross-sectional studies. Thus it is possible that the detected associations reflect the secondary effect of lowback disorders on psychological function. Psychological symptoms occur commonly among individuals with chronic diseases, and in this respect back disorders are no exception (65). However, a few prospective studies have shown that psychological symptoms may also have a role in predicting the future incidence of low-back disorders $(79,112)$.

\section{References}

1. Frymoyer JW, Pope $M H$, Andersson GBJ. Introduction and definitions. In: Pope MH, Frymoyer JW, Andersson G, ed. Occupational low back pain. New York, NY: Praeger Publishers, 1984:xi-xiii.

2. Nachemson A. The lumbar spine - an orthopaedic challenge. Spine 1976;1:59-71.

3. Biering-Sørensen F. A prospective study of low back pain in a general population. Scand J Rehabil Med 1983;15:71-9.

4. Svensson H-O, Andersson GBJ. Low-back pain in forty to forty-seven year old men: work history and work environment. Spine 1983;8:272-6.

5. Vällfors B. Acute, subacute and chronic low back pain: clinical symptoms, absenteeism and working environment. Scand J Rehabil Med 1985;11(suppl 1): 98 p.

6. Nachemson $A$. The natural course of low back pain. In: White AA, Gordon SL, ed. Idiopathic low back pain. St Louis, MO: CV Mosby Company, 1982:4651.

7. Wyke B. The neurology of back pain. In: Jayson MIV, ed. The lumbar spine and back pain. Tunbridge Wells (United Kingdom): Pitman Medical, 1980:265-339.

8. Hirsch C, Ingelmark B-O, Miller M. The anatomical 
basis for low back pain. Acta Orthop Scand 1963;33: $1-17$.

9. Jackson HC, Winkelman RK, Bickel WH. Nerve endings in the human lumbar spinal column and related structures. J Bone Joint Surg 1967;48-A:127281.

10. Vernon-Roberts B, Pirie CJ. Healing trabecular microfractures in the bodies of lumbar vertebrae. Ann Rheum Dis 1973;32:406-12.

11. Vernon-Roberts $\mathbf{B}$. The pathology and interrelation of intervertebral disc lesions, osteoarthrosis of the apophyseal joints, lumbar spondylosis and low back pain. In: Jayson MIV, ed. The lumbar spine and back pain. Tunbridge Wells, (United Kingdom): Pitman Medical, 1980:83-114.

12. Kellgren JH, Lawrence JS. Rheumatism in miners: part II. X-ray study. Br J Ind Med 1952;9:197-207.

13. Hult L. The Munkfors investigation. Acta Orthop Scand Suppl 1954;16: 76 p.

14. Hult L. Cervical, dorsal and lumbar spinal syndromes. Acta Orthop Scand Suppl 1954;17: 102 p.

15. Lawrence JS. Disc degeneration: its frequency and relationship to symptoms. Ann Rheum Dis 1969;28: $121-38$

16. Torgerson WR, Dotter WE. Comparative roentgenographic study of the asymptomatic and symptomatic lumbar spine. J Bone Joint Surg 1976;58-A:840-53.

17. Wiikeri M, Nummi J, Riihimäki $H$, Wickström G. Radiologically detectable lumbar disc degeneration in concrete reinforcement workers. Scand J Work Environ Health 1978;4(suppl 1):47-53.

18. Frymoyer JW, Newberg A, Pope MH, Wilder DG, Clements $\mathbf{J}$, MacPherson B. Spine radiographs in patients with low-back pain. J Bone Joint Surg 1984;66: 1048 - 55 .

19. Biering-Sørensen F, Rolsted Hansen F, Schroll M, Runeborg O. The relation of spinal X-ray to low-back pain and physical activity among 60-year-old men and women. Spine 1985;10:445-51.

20. Splithoff CA. Lumbosacral junction: roentgenographic comparison of patients with and without backaches. JAMA 1953;152:1610-13.

21. Magora A, Schwartz A. Relation between the low back pain syndrome and X-ray findings: I. degenerative osteoarthritis. Scand J Rehabil Med 1976;8:115-25.

22. Witt I, Westergaard A, Rosenklint A. A comparative analysis of $\mathrm{x}$-ray findings of the lumbar spine in patients with and without lumbar pain. Spine 1984;9: 298-300.

23. Riihimäki H, Wickström G, Hänninen K, Mattsson T, Waris P, Zitting A. Radiographically detectable degenerative changes of the lumbar spine as risk indicators of back pain: a cross-sectional epidemiologic study of concrete reinforcement workers and house painters. Scand J Work Environ Health 1989;15:280-5.

24. Smyth MG, Wright V. Sciatica and the intervertebral disc: an experimental study. J Bone Joint Surg 1958; 40-A:1401-18.

25. Mooney V, Robertson J. The facet syndrome. Clin Orthop 1976;115:149-56.

26. Mixter WJ, Barr JS. Rupture of the intervertebral disc with involvement of the spinal canal. N Engl J Med 1934;211:210-5

27. Powell MC, Wilson M, Szypryt P, Symonds EM, Worthington BS. Prevalence of lumbar disc degeneration observed by magnetic resonance in symptomless women. Lancet 1986;1:1366-7.

28. Boden SD, Davis DO, Dina TS, Patronas NJ, Wiesel $S$. The incidence of abnormal lumbar spine MRI scans in asymptomatic patients: a prospective and blinded investigation [Abstract]. International Society for the Study of the Lumbar Spine. 16th annual meeting, International Society for the Study of the Lumbar Spine,
Kyoto, Japan, May 15-19, 1989. Kyoto: International Society for the Study of the Lumbar Spine, 1989:37.

29. Massie NK, Stevens DB. A critical evaluation of discography. J Bone Joint Surg 1967;49:1243-4.

30. Holt EP Jr. The question of lumbar discography. J Bone Joint Surg 1968;50-A:720—6.

31. Walsh TR, Weinstein JN, Spratt KF, Lehman TR, Aprill CN, Sayre H. Lumbar discography: a controlled prospective study of normal volunteers to determine false-positive rate [Abstract]. International Society for the Study of the Lumbar Spine. 16th annual meeting, International Society for the Study of the Lumbar Spine, Kyoto, Japan, May 15-19, 1989. Kyoto: International Society for the Study of the Lumbar Spine, 1989:37.

32. Porter RW, Hibbert C, Wellman P. Backache and the lumbar spinal canal. Spine 1980;5:99-105.

33. Macdonald EB, Porter R, Hibbert $C$, Hart J. The relationship between spinal canal diameter and back pain in coal miners: ultrasonic measurement as a screening test? J Occup Med 1984;26:23-8.

34. Murphy RW. Nerve roots and spinal nerves in degenerative disk disease. Clin Orthop 1977;129:46- 60 .

35. Kelsey JL. An epidemiological study of acute herniated lumbar intervertebral discs. Rheumatol Rehabil 1975; $14: 144-55$.

36. Kelsey JL. An epidemiological study of the relationship between occupations and acute herniated lumbar intervertebral discs. Int J Epidemiol 1975;4:197-205.

37. Kelsey JL, Githens PB, White AA, et al. An epidemiologic study of lifting and twisting on the job and risk for acute prolapsed lumbar intervertebral disc. J Orthop Research 1984;2:61-6.

38. Kelsey JL, Githens PB, O'Connor T, et al. Acute prolapsed lumbar intervertebral disc: an epidemiologic study with special reference to driving automobiles and cigarette smoking. Spine 1984;9:608-13.

39. Heliövaara M. Epidemiology of sciatica and herniated lumbar intervertebral disc. Helsinki: The Social Insurance Institution, 1988. (Publication ML:76.)

40. Eyring EJ. The biochemistry and physiology of the intervertebral disc. Clin Orthop 1969;67:16-28.

41. Brodin H. Paths of nutrition in articular cartilage and intervertebral discs. Acta Orthop Scand 1955;24:17783.

42. Nachemson A, Lewin T, Maroudas A, Freeman MAR. In vitro diffusion of dye through the end-plates and annulus fibrosis of lumbar intervertebral discs. Acta Orthop Scand 1970;41:589-607.

43. Beard HK, Stevens RL. Biochemical changes in the intervertebral disc. In: Jayson MIV, ed. The lumbar spine and back pain. Tunbridge Wells (United Kingdom): Pitman Medical, 1980:407-36.

44. Macnab I. Disc degeneration and low back pain. Clin Orthop 1986;208:3-14.

45. White AA, Gordon SL. Synopsis: workshop on idiopathic low-back pain. Spine 1982;7:141-9.

46. Brown T, Hansen RJ, Yorra AJ. Some mechanical tests on the lumbosacral spine with particular reference to the intervertebral discs. J Bone Joint Surg 1957;39-A: 1135.

47. Farfan HF. Mechanical disorders of the low back. Philadelphia, PA: Lea and Febiger, 1973.

48. Brinckmann P, Biggemann M, Hilweg D. Fatigue fracture of human lumbar vertebrae. Clin Biomech 1988;3 (suppl 1):1-23.

49. Pope MH, Lehman TR, Frymoyer JW. Structure and function of the lumbar spine. In: Pope MH, Frymoyer JW, Andersson G, ed. Occupational low back pain. New York, NY: Praeger Publishers, 1984:5-38.

50. Quinnell RC, Stockdale HR. The significance of osteophytes on lumbar vertebral bodies in relation to discographic findings. Clin Radiol 1982;33:197- 203. 
51. Butler D, Trafimow JH, Andersson GBJ, McNeill TW, Huckman MS. Discs degenerate before facets. Spine 1990;15:111-3.

52. Malmivaara $\mathbf{A}$. Thoracolumbar junctional region of the spine: an anatomical, pathological and radiological study [Doctoral dissertation]. Helsinki: University of Helsinki, 1987.

53. Grabias SL, Mankin HJ. Pain in the lower back. Bull Rheum Dis 1980;30:1040-5.

54. Nachemson AL, Andersson GBJ. Classification of lowback pain. Scand J Work Environ Health 1982;8: 134-6.

55. Anonymous. Progress in back pain? Lancet 1981;1: 977-9.

56. Rowe ML. Low back pain in industry: a position paper. J Occup Med 1969;11:161 -9.

57. Leavitt SS, Johnston TL, Beyer RD. The process of recovery: patterns in industrial back injury: part 2 predicting out-comes from early case data. Ind Med Surg 1971;40:7-15.

58. Cöhler U, Larsson R, Nachemson A, Peterson L-E. Förenklad behandling av patienter med lumbala smärtor: relativt smá insatser kan spara mycket mänskligt lidande. [Simplified treatment of patients with lumbar pain: relatively small effort can save much human suffering]. Läkartidningen 1989;86:2362-67.

59. Hildebrandt VH. A review of epidemiological research on risk factors of low back pain. In: Buckle PW, ed. Musculo-skeletal disorders at work. London: Taylor \& Francis, 1987:9-16.

60. Jayson MIV, ed. The lumbar spine and back pain. Tunbridge Wells (United Kingdom): Pitman Medical, 1980.

61. White AA, Gordon SL, ed. Idiopathic low back pain. St Louis, MO: CV Mosby Company, 1982.

62. Pope MH, Frymoyer JW, Andersson G, ed. Occupational low back pain. New York, NY: Praeger Publishers, 1984.

63. Troup JDG. Causes, prediction and prevention of back pain at work. Scand J Work Environ Health 1984;10 419-28.

64. Yu T-S, Roht LH, Wise RA, Kilian J, Weir FW. Lowback pain in industry: an old problem revisited. J Occup Med 1984;26:517-24.

65. Sievers K. Mäkelä M, Raitasalo R. Somaattinen sairastavuus psyykkisen oireilun selittäjänä [Somatic morbidity as an explanatory factor of psychic symptoms]. Sosiaalivakuutus 1989;4:161-5.

66. Lawrence JS. Rheumatism in coal miners: part III. occupational factors. Br J Ind Med 1955;12:249-61.

67. Ikata $T$. Statistical and dynamic studies of lesions due to overloading of the spine. Shikoku Acta Med 1965; 40:262-86

68. Magora A. Investigation of the relation between low back pain and occupation: II. work history. Ind Med Surg 1970;39:504-10.

69. Gyntelberg F. One year incidence of low back pain among male residents of Copenhagen aged 40-59. Dan Med Bull 1974;21:30-6.

70. Wickström $G$, Hänninen $K$, Lehtinen $M$, Riihimäki $H$. Previous back syndromes and present back symptoms in concrete reinforcement workers. Scand J Work Environ Health 1978;4(suppl 1):20-8.

71. Valkenburg HA, Haanen HCM. The epidemiology of low back pain. Clin Orthop 1983;179:9-22.

72. Videman $T$, Nurminen $T$, Tola $S$, et al. Low-back pain in nurses and some loading factors of work. Spine 1984;9:400-4.

73. Lloyd MH, Gauld S, Soutar CA. Epidemiologic study of back pain in miners and office workers. Spine 1986; 11:136-40.

74. Partridge RE, Duthie JJR. Rheumatism in dockers and civil servants: a comparison of heavy manual and seden- tary workers. Ann Rheum Dis 1968;27:559-68.

75. Sairanen E, Brüshaber L, Kaskinen M. Felling work, low-back pain and osteoarthritis. Scand J Work Environ Health $1981 ; 7: 18-30$.

76. Riihimäki $H$. Back pain and heavy physical work: a comparative study of concrete reinforcement workers and house painters. Br J Ind Med 1985;42:226-32.

77. Heliövaara M. Occupation and risk of herniated lumbar intervertebral disc or sciatica leading to hospitalization. J Chronic Dis 1987;40:259-64.

78. Leino P, Hasan J, Karppi S-L. Occupational class, physical work load, and musculoskeletal morbidity in the engineering industry. $\mathrm{Br} \mathrm{J}$ Ind Med 1988;45:67281 .

79. Biering-Sørensen F, Thomsen C. Medical, social and occupational history as risk indicators for low-back trouble in a general population. Spine 1986;11:720 - -5.

80. Caplan PS, Freedman LMJ, Connelly TP. Degenerative joint disease of the lumbar spine in coal miners - a clinical and X-ray study. Arthritis Rheum 1966;9: $693-702$.

81. Riihimäki H, Mattsson $\mathrm{T}$, Zitting A, Wickström $\mathrm{G}$, Hänninen K, Waris P. Radiographically detectable degenerative changes of the lumbar spine among concrete reinforcement workers and house painters. Spine 1990; 15:114-9.

82. Hansson T. Ländryggsbesvär och arbete [Low-back pain and work]. Stockholm: Arbetsmiljöfonden, 1989.

83. Porter RW, Adams MA, Hutton WC. Physical activity and the strength of the lumbar spine. Spine 1989; 14:201-3.

84. Bigos SJ, Spengler DM, Martin NA, et al. Back injuries in industry: a retrospective study: II. injury factors. Spine 1986;11:246-51.

85. Magora A. Investigation of the relation between low back pain and occupation: III. physical requirements: sitting, standing and weight lifting. Ind Med Surg 1972; 41:5-9.

86. Magora A. Investigation of the relation between low back pain and occupation: IV. physical requirements: bending, rotation, reaching and sudden maximal effort. Scand I Rehabil Med 1973;5:186-90.

87. Chaffin DB, Park KS. A longitudinal study of low-back pain as associated with occupational weight lifting factors. Am Ind Hyg Assoc J 1973;34:513-25.

88. Frymoyer JW, Pope MH, Constanza MC, et al. Epidemiologic studies of low back pain. Spine 1980;5: $419-23$.

89. Frymoyer JW, Pope MH, Clements JH, Wilder DG, MacPherson B, Ashikaga T. Risk factors in low back pain: an epidemiological survey. J Bone Joint Surg $1983 ; 65-\mathrm{A}: 213-8$.

90. Damkot DK, Pope MH, Lord J, Frymoyer JW. The relationship between work history, work environment and low-back pain in men. Spine 1984;9:395-9.

91. Penttinen J. Back pain and sciatica in Finnish farmers. Helsinki: The Social Insurance Institution, 1987. (Publications ML;71.)

92. Maeda K, Okazaki F, Svenaga T, et al. Low back pain related to bowing posture of greenhouse farmers. $J$ Hum Ergol 1980;9:117-23.

93. Keyserling WM, Punnett L, Fine LJ. Trunk posture and back pain: identification and control of occupational risk factors. Appl Ind Hyg 1988;3:87-92.

94. Riihimäki H, Tola S, Videman T, Hänninen K. Lowback pain and occupation: a cross-sectional questionnaire study of men in machine operating, dynamic physical work and sedentary work. Spine 1989;14:204-9.

95. Gruber GJ. Relationship between whole-body vibration and morbidity patterns among interstate truck drivers. US Department of Health Education and Welfare, 1976. (Publication; no 77-167.)

96. Brendstrup T, Biering-Sørensen F. Effect of fork-lift 
truck driving on low-back trouble. Scand J Work Environ Health 1987;13:445-52.

97. Hrubeck Z, Nashold BS. Epidemiology of lumbar disc lesions in the military in World War II. Am J Epidemiol $1975 ; 102: 366-76$.

98. Kelsey JL, Hardy RJ. Driving motor vehicles as risk factor for acute herniated lumbar intervertebral disc. Am J Epidemiol 1975;102:63-73.

99. Bongers PM, Boshuizen HC, Hulshof CTJ, Koemeester AP. Back disorders in crane operators exposed to whole-body vibration. Int Arch Occup Environ Health 1988:60:129-37.

100. Köhl U. Les dangers encourus par les conducteurs de tracteurs. Arch Mal Prof Med Trav Secur Soc 1975; 36:145-62

101. Dupuis $H$, Zerlett $G$. Whole-body vibration and disorders of the spine. Int Arch Occup Environ Health 1987;59:323-36.

102. Troup JDG. Driver's back pain and its prevention: a review of the postural, vibratory and muscular factors, together with the problem of transmitted road shock. Appl Ergon 1978;9:207-14.

103. Troup JDG. Clinical effects of shock and vibration on the spine. Clin Biomech 1988;3:227-31.

104. Bergquist-Ullman M, Larsson U. Acute low back pain in industry: a controlled prospective study with special reference to therapy and confounding factors. Acta Orthop Scand Suppl 1977;170:177 p.

105. Svensson H-O, Andersson GBJ. The relationship of low-back pain, work history, work environment and stress: a retrospective cross-sectional study of 38 - to 64-year-old women. Spine 1989;14:517-22.

106. Reisbord LS, Greenland S. Factors associated with selfreported back-pain prevalence: a population based study. J Chronic Dis 1985;38:691-702.

107. Nachemson A, Elfström G. Intravital dynamic pressure measurements in lumbar discs. Scand $\mathbf{J}$ Rehabil Med Suppl 1970;1.

108. Andersson GBJ, Örtengren R, Nachmson A, Elfström G. Lumbar disc pressure and myoelectric back muscle activity during sitting: I. studies on an experimental chair. Scand J Rehabil Med 1974;6:104- 14.

109. Holm S, Nachemson A. Variations in the nutrition of canine intervertebral disc induced by motion. Spine 1983;8:866-74.

110. Magora A. Investigation of the relation between low back pain and occupation. V. psychological aspects. Scand J Rehabil Med 1973;5:191-6.

111. Kelsey JL, Golden AL. Occupational and workplace factors associated with low back pain. In: Deyo RA, ed. Back pain in workers. Philadelphia, PA: Hanley \& Belfus, 1988:7-16. (Occupational medicine: state of the art reviews 3.)

112. Bigos SJ, Battié MC, Spengler DM, et al. A prospective study of work perceptions and psychosocial factors affecting the report of back injury. Spine (in press).

113. Lloyd DCEF, Troup JDG. Recurrent back pain and its prediction. J Soc Occup Med 1983;33:66-74.

114. Manning DP, Mitchell RG, Blanchfield LP. Body movements and events contributing to accidental and nonaccidental back injuries. Spine 1984;9:734-9.

115. Riihimäki $H$, Wickström $G$, Hänninen $K$, Luopajärvi $T$. Predictors of sciatic pain among concrete reinforcement workers and house painters - a five-year followup. Scand J Work Environ Health 1989;15:415-23.

116. Sims-Williams H, Jayson MIV, Baddeley H. Small spinal fractures in back pain patients. Ann Rheum Dis 1978;37:262-5.

117. Farfan HF, Cossette JW, Robertson GH, et al. The effects of torsion on the lumbar intervertebral joints: the role of torsion in the production of disc degeneration. J Bone Joint Surg 1970;52-A:468-97.

118. Troup JDG. Relation of lumbar spine disorders to heavy manual work and lifting. Lancet 1965;1:85761.

119. Frymoyer JW, Pope HP. The role of trauma in low back pain: a review. J Trauma 1978;18:628-34.

120. Horal J. The clinical appearance of low back disorders in the city of Gothenburg, Sweden. Acta Orthop Scand Suppl 1969;118:109 p.

121. Klaukka T, Sievers K, Takala J. Epidemiology of rheumatic diseases in Finland in 1964-76. Scand J Rheumatol Suppl 1982;47:5-15.

122. Battié MC, Bigos SJ, Fisher LD, et al. A prospective study of the role of cardiovascular risk factors and fitness in industrial back pain complaints. Spine 1989; 14:141-7.

123. Takala J, Sievers K, Klaukka T. Rheumatic symptoms in the middle-aged population in southwestern Finland. Scand J Rheumatol Suppl 1982;47:15-29.

124. Heliövaara M. Body height, obesity, and risk of herniated intervertebral disc. Spine 1987;12:469-72.

125. Rowe ML. Low back disability in industry: updated position. J Occup Med 1971;13:476-8.

126. Deyo RA, Bass JE. Lifestyle and low-back pain: the influence of smoking and obesity. Spine 1989;14: $501-6$.

127. Aro S, Leino P. Overweight and musculoskeletal morbidity: a ten-year follow-up. Int J Obesity 1985;9: 267-74.

128. Cady LD, Bishoff DP, O'Connell ER, Thomas PC, Allan JH. Strength and fitness and subsequent back injuries in fire-fighters. J Occup Med 1979;4:269-72.

129. Nummi J, Järvinen T, Stambeij U, Wickström G. Diminished dynamic performance capacity of back and abdominal muscles in concrete reinforcement workers. Scand J Work Environ Health 1978;4(suppl 1):39-46.

130. McNeill T, Warwick D, Andersson G, Schultz A. Trunk strength in attempted flexion, extension and lateral bending in healthy subjects and patients with low back disorders. Spine 1980;5:529-38.

131. Smidt G, Herring T, Amundsen L, Rogers M, Russel A, Lehman T. Assessment of abdominal and back extensor function: a quantitative approach and results for chronic low-back patients. Spine 1983;8:211-9.

132. Biering-Sørensen F. Physical measurements as risk indicators for low back trouble over a one-year period. Spine 1984;9:106-19.

133. Mayer TG, Smith SS, Keeleyn J, Mooney V. Quantification of lumbar function: part 2. sagittal plane trunk strength in chronic low back pain patients. Spine 1985;10:765-72.

134. Pope MH, Bevins MJ, Wilder DG, Frymoyer JW. The relationship between anthropometric, postural, muscular and mobility characteristics of males aged 18-55. Spine 1985;10:644-8.

135. Leino $\mathrm{P}$, Aro S, Hasan J. Trunk muscle function and low back disorders: a ten-year follow-up study. J Chronic Dis 1987;40:289-96.

136. Battié MC, Bigos SJ, Fisher L, Hansson TH, Jones $\mathrm{ME}$, Wortley MD. Isometric lifting strength as a predictor of industrial back complaints. Spine 1989;14: $851-6$.

137. Svensson H-O, Wilhelmsson C, Andersson GBJ. Lowback pain in relation to other diseases and cardiovascular risk factors. Spine 1983;8:277-85.

138. Heliövaara $M$, Knekt $P$, Aromaa A. Incidence and risk factors of herniated lumbar intervertebral disc or sciatica leading to hospitalization. J Chronic Dis 1987;40:251-8.

139. Holm S, Nachemson A. Nutrition of the intervertebral disc: acute effects of cigarette smoking: an experimental study. Uppsala J Med Sci 1988;93:91-9.

140. Gentry WD, Shows WD, Thomas M. Chronic back pain: a psycho-logical profile. Psychcsomatics 1974; 15:174-7. 
141. Gilchrist IC. Psychiatric and social factors related to low back pain in general practice. Rheumatol Rehabil 1976;15:101-7.

142. Donovan WH, Dwyer AP, White BWS, et al. A multidisciplinary approach to chronic low back pain in western Australia. Spine 1981;6:591-7.

143. Joukamaa M. Alaselän kipu ja psyykkiset tekijät: yyöikäiseen väestöön kohdistuva sosiaalipsykiatrinen tut- kimus. [Low-back pain and psychological factors: a sociopsychiatric study of the working age population]. Turku (Finland): Kansaneläkelaitos, 1986. (Julkaisuja AL:28)

Received for publication: 4 January 1991 